\title{
How thalidomide makes its mark
}

\section{サリドマイドが作用する仕組み}

Heidi Ledford doi:10.1038/news.2009.462/11 May 2009

胎児の血管新生に薬剤が及ぼす作用が、手足の形成異常の原因とみられる。

妊婦のつわりを軽減する薬としてサリドマ イドが売り出されてから、かれこれ 50 年 以上経った。このたびようやく、この薬 剂が重度の出生時欠損を引き起こす仕組 みが明らかになったようである。

アバディーン大学（英国）のNeil Vargessonらは、ニワトリでの実験によ り、妊娠初期のサリドマイド服用が原因で 手足に奇形のある子どもが生まれたこと に、この薬の血管新生を阻害する作用が

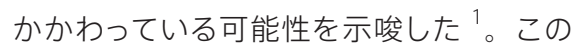
知見は、こうした副作用のない、類似の 化合物を開発するうえで役立つものと考 えられる。

1961 年にサリドマイドが市場から回収 されるまでに、手足の奇形やその他の出 生時欠損をもって生まれた子どもの数は 1 万人に上った。その後、この薬剤は八 ンセン病や多発性骨髄腫の治療薬として、 市場に再登場した。米国ではサリドマイド の入手が厳重に規制されており、女性の 場合、月 1 回の妊娠検査の結果が陰性で なければ、処方してもらえない。しかし、

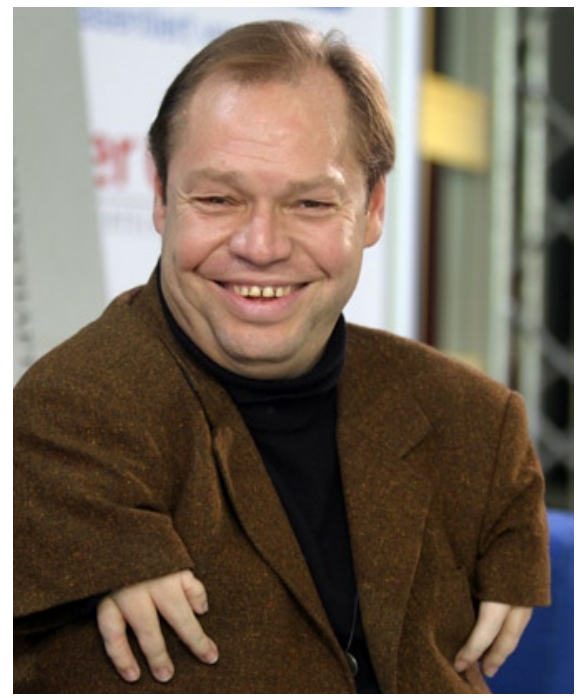

サリドマイド禍被害者である、世界的に有名なド イツ人バリトン歌手トーマス・クヴァストホフ。
一部の国々では、サリドマイドの入手がた やすく、そのため、出生時欠損が再び問 題化する可能性がある。

\section{扱いの難しい治療薬}

しかし、サリドマイドは研究するのが難し い薬剂である。この化合物は肝臓で代謝 的に活性化され、そこで分解されて、お そらく 100 種類以上の化合物が生成す る。これらのそれぞれ（もしくは、どれか の組み合わせ）が、四肢の形成異常の原 因になっている可能性がある。そのうえ、 サリドマイドは、実験に広く使われている マウスやラットなどの動物では、それほど 重度の出生時欠損を引き起こさない。

Vargessonの共同研究者で、米国立 がん研究所（メリーランド州ベセスダ）の 薬理学者William Figg は、サリドマイド の多数ある代謝産物を特定し単離すること に着手した。そのおかげで、Vargesson たちはニワトリでこれらの代謝化合物の作 用を調べることができた。ニワトリは、サ リドマイドで出生時欠損が生じる動物モデ ルの 1 つである。探索の結果、サリドマイ ドの分解産物に化学的 ·構造学的に似て いて、重度の四肢欠損症を引き起こす化 合物が 1 つ浮かび上がった。この化合物 は CPS49 とよばれるもので、新しい血管 の発生を阻害することがわかっている。

そして、ニワトリの胚で、妊婦のサリ ドマイド服用時期に当たる発生時期に CPS49 を投与したところ、四肢の発生に 選択的に作用し、胚のその他の部分には 影響がないという、めざましい結果が得ら れた。Vargesson によると、その時期の ニワトリ胚では、胴体部分の血管はかなり でき上がっているが、四肢の血管はちょう どでき始める時期に当たるという。また、 それよりも早い、ニワトリの胚で血管が構 築されようとしている時期に、CPS49を
投与すると、胚が死んでしまった。一方、 四肢の血管形成の時期よりも遅い時期に CPS49 を投与した場合、四肢の形成異 常はさほど重症にならなかった。

Vargessonはこの何年かの間に、サ リドマイドの悲惨な副作用を説明しようと する 30 種類以上の仮説を検討しており、 血管成長の阻害もそのうちの 1 つだった。 しかし、それらの仮説の中に、阻害作用 を裏付ける十分なデータがあるものはほ とんどなかった。今回の研究によって、 血管新生の阻害が重要な原因の 1 つであ ることがはっきり確認できたのだと、ケル ン大学（ドイツ）の細胞生物学者である Jürgen Knobloch は話す。

Knoblochの研究チームは以前、発 生中のニワトリの四肢の細胞をサリドマイ ドにさらすと、活性酸素によってストレス が生じることを明らかにしている ${ }^{2}$ 。「スト レスが生じた結果として、細胞の生存に 不可欠な一部のシグナル伝達経路が減弱 する方向に調節 (下方制御) されるので す」と彼はいう。Vargessonたちの研 究結果は、遺伝子発現の変化が血管成長 の阻害後にしか起こらないことを示してい るので、酸化ストレスはサリドマイドが血 管に及ぼす作用の下流に当たるのではな いかと、Knobloch は考えている。

これらの研究結果は、サリドマイドが 手足に及ぼす影響を説明するうえで重要 なものだが、同じくサリドマイドによって 起こる神経や耳への影響といった、重大 なほかの出生時欠損への取り組みはな されていないと、マサチューセッツ小児 総合病院（米国、ボストン）の Lewis Holmes はいう。そして「まだ謎は残さ れているのです」と締めくくった。

1. Therapontos, C. et al. Proc. Natl Acad. Sci. USA doi:10.1073/ pnas. 0901505106 (2009).

2. Knobloch, J. et al. FASEB J. 21, 1410-1421 (2007). 